\title{
Butterfly Species Diversity in Protected and Unprotected Habitat of Ise Forest Reserve, Ise Ekiti, Ekiti State
}

\author{
Jacob Olufemi Orimaye, ${ }^{1}$ Olumide Odunayo Ogunyemi, ${ }^{1}$ Ehi Francis Okosodo, ${ }^{2}$ \\ Victor Abiodun Ojo, ${ }^{3}$ and Tejumola Olayinka Agbelusi ${ }^{1}$ \\ ${ }^{1}$ Department of Forest Resources and Wildlife Management, Ekiti State University, Ado Ekiti, Nigeria \\ ${ }^{2}$ Department of Ecotourism and Wildlife Management, Federal University of Technology, Akure, Nigeria \\ ${ }^{3}$ Department of Forestry and Wildlife Management, University of Maiduguri, Maiduguri, Nigeria
}

Correspondence should be addressed to Jacob Olufemi Orimaye; jacob.orimaye@eksu.edu.ng

Received 10 June 2016; Revised 6 August 2016; Accepted 29 August 2016

Academic Editor: Dafeng Hui

Copyright (C) 2016 Jacob Olufemi Orimaye et al. This is an open access article distributed under the Creative Commons Attribution License, which permits unrestricted use, distribution, and reproduction in any medium, provided the original work is properly cited.

\begin{abstract}
This study investigated butterfly diversity in the protected area (PA) and unprotected area (UPA) of Ise Forest reserve, Ise Ekiti, Ekiti State, using sweep net along existing trails. Butterfly species seen in the study sites were captured and released after proper identification was made. The results indicated that a total of 837 butterflies were identified in the study sites with 661 species observed in PA and 176 species in UPA. Butterfly species diversity was significantly different $(p \leq 0.05)$ between PA and UPA. Shannon diversity index was higher in PA (3.59) than UPA (3.27) as against Menhinick's index, higher in UPA (2.11) than in PA (1.52). Likewise, 10 families of butterflies were recorded in PA and 8 families in UPA. The family with highest species occurrence was Satyridae (17.9\%) in PA and Lycaenidae in UPA with 20.1\%. Butterfly families' diversity was not significant $(p \geq 0.05)$ between the two study sites. Ise Forest Reserve recorded approximately $6.6 \%$ of all butterflies recorded in West Africa. The findings indicated that mature secondary and regenerated forests supported high butterfly diversity and species richness, while cultivated land and grassland had a negative impact on butterfly community suggesting the negative effect of agricultural activities on the ecosystem.
\end{abstract}

\section{Introduction}

There is a disparity in the ecological niche for different habitats and many species of plants and animals are limited in ecological capabilities yet some are constrained to one or a small set of habitat [1]. A significant reduction in butterfly diversity is becoming gradually noticeable [2] and this reduction in diversity is largely caused by anthropogenic activities in and around their habitats [3]. However, there is a lot of anxiety on the status of the earth's biodiversity [4] and from this observation, biodiversity is being rapidly depleted resulting in a threat to the continued support that nature make available for human existence and development [5]. Several animal species could tolerate only a limited level of human disturbances in their natural environments [6]. This is of special significance to Nigerian landscapes where human impact on land use for several hundreds of years changed the great majority of natural habitats [7]. One of the group of animals with diverse species richness is insects which represent over $50 \%$ of terrestrial biodiversity. Butterflies, unlike most of other groups of insects, are popular, welldocumented, and easy to recognize. They are well adapted to the landscape and react quickly to any alteration in their habitat as a result of human-induced activities such as farmland intensification [8] and intensive logging. A viable butterfly population depends on a connection of breeding habitats scattered over the landscape which makes butterflies particularly susceptible to habitat fragmentation [9]. Moreover, the phenomenon of climate change affects quite a lot of butterflies and this has been used as a model to predict the impact of climate change on wildlife. This, however, has made butterflies one of the best species groups for monitoring biodiversity changes [9]. To this effect, Brown [10] identified that plant plays an important role in butterfly biodiversity, emphasizing that the value of the diversity of any ecosystem is viewed from the perspective of the number of species 


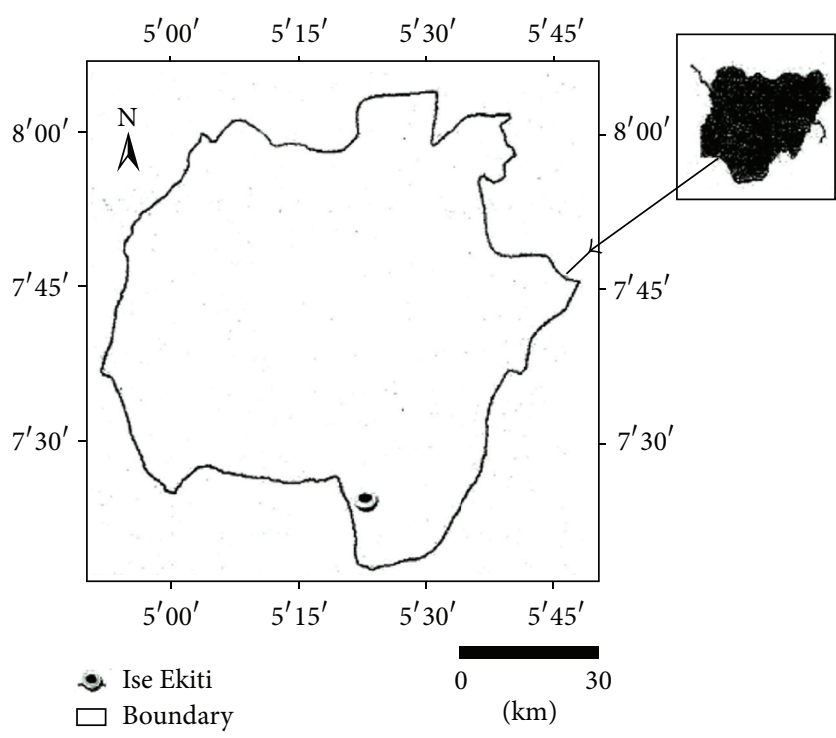

Figure 1: Map of the study areas.

intermingling among themselves and with their physical environment. This paper, therefore, seeks to explore the differences in butterfly species composition in the protected and unprotected habitat of Ise Forest Reserve, Ekiti State.

\section{Methodology}

The study was carried out in Ise Forest Reserve, Ekiti State, Nigeria. Ise Forest Reserve covers $56.77 \mathrm{~km}^{2}$, with latitude $7.38\left(7^{\circ} 2260 \mathrm{~N}\right)$ and a longitude of $5.37\left(5^{\circ} 220 \mathrm{E}\right)$. The reserve can be accessed from Ise Ekiti town which is about $6 \mathrm{~km}$ in a straight direction to the northern edge of the reserve (Figure 1).

2.1. Data Collection. Three transects of $1 \mathrm{~km}$ (which has 20 sections of $50 \mathrm{~m}$ each) were selected from the existing trails in the protected area (PA) and unprotected area (UPA) of Ise Forest Reserve. The transect in each site was sampled 14 times for butterfly early in the morning when butterflies were active. Butterfly species seen within the range of $2.5 \mathrm{~m}$ to each side and $5 \mathrm{~m}$ in front and above were trapped using an improvised sweep net and released after proper identification [9]. All the captured butterflies that were not identified in the field were put in specimen bottles containing ethyl acetate soaked in cotton wool kept in the bottom of the jar and were later identified using the field guide to butterflies of West Africa [11] for both protected and unprotected habitats. The ecological composition of butterflies in the study areas was compared with the available knowledge of 1,000 species of butterflies recorded by Akwashiki et al. [12] for West Africa using the method of Nwosu and Iwu (Figure 2) [13].

2.2. Data Analysis. The computer model PAST, version $3^{\mathrm{TM}}$, was used to compute diversity indices such as ShannonWeiner index and the Simpson index of dominance in order to compare the diversities of butterflies of the two study areas. Ecological composition of butterflies in the

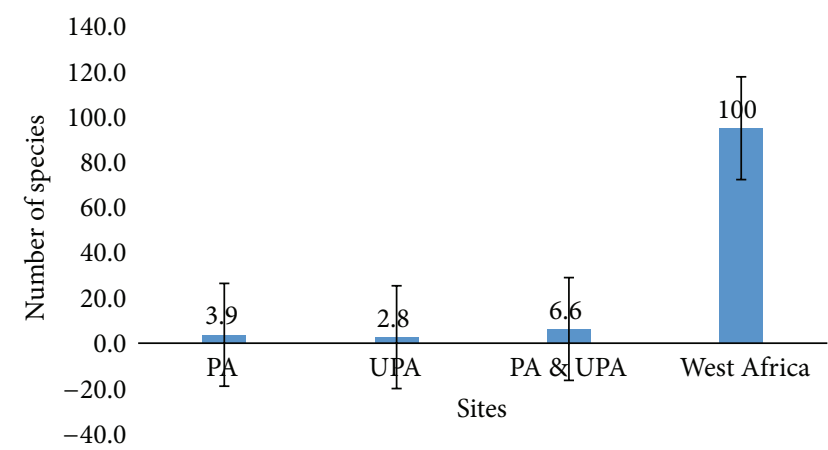

FIgURE 2: Comparison between the ecological composition of butterflies and the current composition of butterflies of West Africa in the study areas.

study area was calculated using the following formula: $(y / 1000$ species $)(100 / 1) \%$, where $y$ is the total number of species of butterflies identified in the study areas. Student's $t$ test was used to compare the differences in the mean of data collected from the two study sites and descriptive statistics such as frequency tables, charts, and percentages were used to describe results.

\section{Results}

3.1. Butterfly Species Diversity in the Study Areas. Data of butterfly species diversity is presented in Table 1 . A total of individual 837 butterflies were identified in the study areas. Thirty-nine species were observed in PA with Cymothoe egesta of the family Lycaenidae having the highest abundance of $4.2 \%$, followed by Citrinophila marginalis of the family Lycaenidae and Mylothris chloris of Pieridae family which recorded the same value of $3.8 \%$ while Pseudacraea striata of the family Nymphalidae had the least abundance of $0.8 \%$ of the total butterflies observed in PA. In the unprotected area of the reserve, a total of 28 species of butterflies were recorded with Eritis melania belonging to family Hesperidae having the highest abundance of $6.1 \%$ while Euphura chalcis of Lycaenidae (1.0\%) recorded the least occurrence value. Butterfly species diversity was significantly different $(p \leq$ $0.05)(t=0.001)$ between PA and UPA.

3.2. Biodiversity Indices of Butterfly Species in the Study Area. The number of the different species and the number of individuals within each species of butterfly in the study areas (Shannon-Wiener diversity index) were higher in PA (3.59) than in UPA (3.27). The number of species found in the study areas (Menhinick's index) was higher in UPA (2.11) than in PA (1.52) (Table 2).

3.3. Diversity of Butterfly Family in the Study Areas. A total of 10 families representing $56 \%$ were identified at the PA and 8 families representing $44 \%$ of the collected butterfly were recorded in UPA of Ise Forest Reserve, Ekiti State, during the study period. Butterflies belonging to the family Satyridae were most abundant, representing $17.9 \%$ of the total butterflies identified in PA and the least abundance of $2.6 \%$ 
TABLE 1: Butterfly species diversity in the study areas.

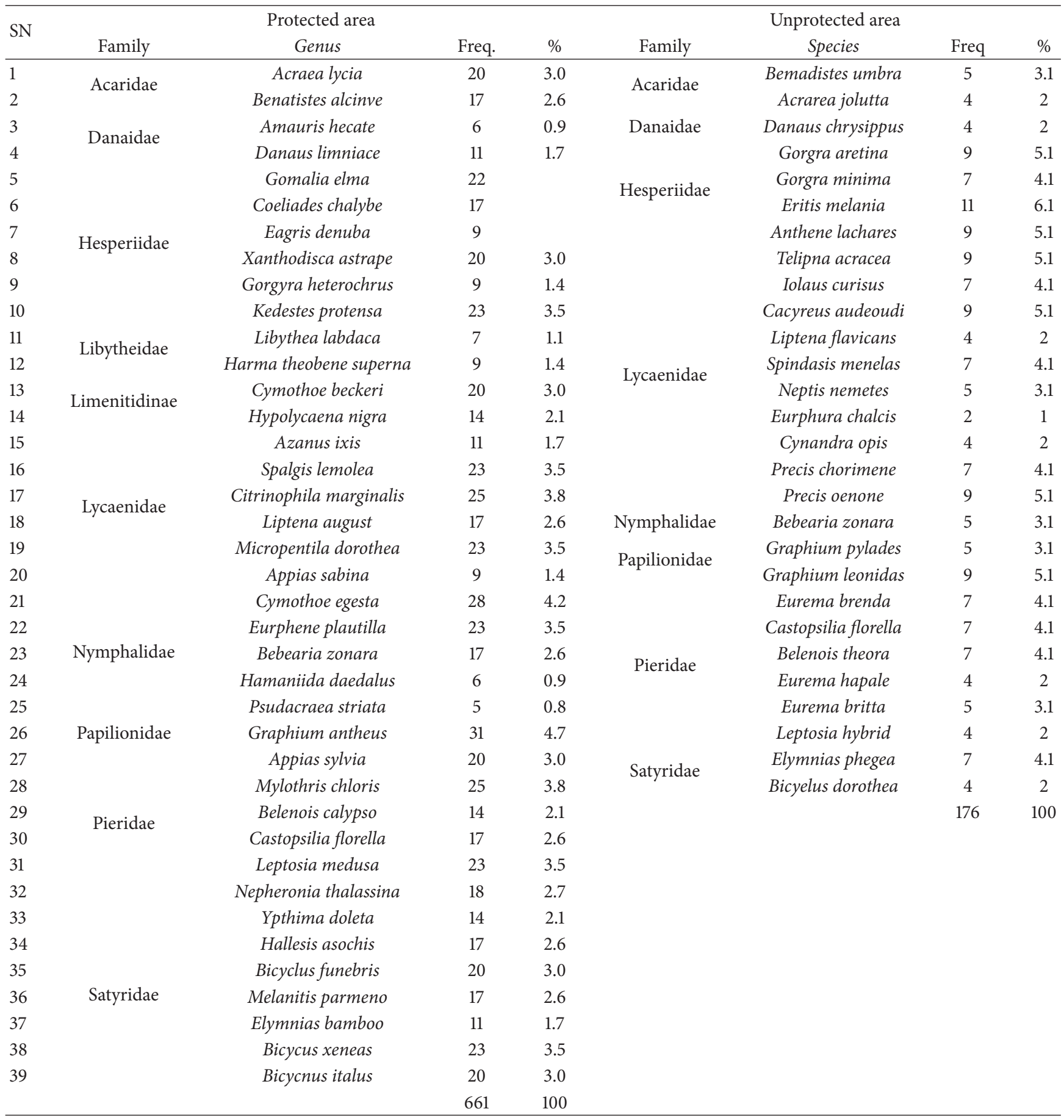

was observed for Papilionidae. Lycaenidae (35.7\%), Pieridae (21.4\%), and Hesperiidae (14.3\%) were the most abundant species in UPA, respectively, whereas the families Libytheidae and Limenitidinae were completely absent.

\section{Discussion}

A total of 66 species of butterflies belonging to 10 families were identified during the study period from two sampled sites, namely, the protected and unprotected areas of Ise
Forest Reserve. Butterfly species belonging to Satyridae and Lycaenidae families were the most abundant, accounting for $17.9 \%$ and $35.7 \%$ of the butterflies collected at PA and UPA of Ise Forest Reserve, Ise Ekiti, respectively. These observations corroborated with the observation of Brown [10], Akwashiki et al. [12], Nwosu and Iwu [13], and Kemabontal et al. [14] who reported these families as the largest of the Lepidoptera order. The high occurrence of these families in the two study areas has a positive effect for pollination in these areas because they are among the exceptional fruit-feeding butterfly community 
TABLE 2: Biodiversity Indices of butterfly species in the study area.

\begin{tabular}{lcc}
\hline & PA & UPA \\
\hline Taxa_S & 39 & 28 \\
Individuals & 661 & 176 \\
Dominance_D & 0.03 & 0.04 \\
Shannon_H & 3.59 & 3.27 \\
Menhinick & 1.52 & 2.11 \\
\hline
\end{tabular}

[15]. The abundance of Satyridae in the PA of Ise Forest Reserve also agrees with the observation of Nwosu and Iwu [13] where members of Satyridae were reported to be abundant in PA of Okwu Ogbaku forest reserve, Mbaitoli, Nigeria. Also, the study recorded a relatively high diversity of butterfly species and species richness in PA compared to UPA [15].

The higher diversity, minimum dominance, and occurrence of 10 unique families of butterflies recorded in PA as against 8 recorded in UPA may be attributable to the vegetation complexity and multilayered canopy of the PA, which facilitate different sets of microclimates, making the habitat distinct for different butterfly species [16]. Diversity is enhanced by the presence of specialists that exhibit distinct habitat preferences [17, 18].

Most of the African butterfly species are restricted to one or a smaller number of ecological zones and are, therefore, found in specific habitats [19]. For instance, there is a large difference in the total number of species found between the fauna of the forest (PA) and the derived savanna (UPA) separated by the guinea savanna [20]. Viejo et al. [21] documented about 2000 species of butterflies in West Africa. In 2005, Larsen [11] reported that the butterflies of West Africa (west of the Dahomey Gap) consist of approximately 1,000 species. Overall butterfly species recorded for the study area were 66 species translating to $6.6 \%$ of the 1000 species of butterfly in West Africa. This might be due to climate change effects on the vegetation which invariably affect the diversity of butterfly in the study areas.

\section{Conclusion}

The findings indicated that mature secondary and regenerated forests (PA) supported high butterfly diversity and species richness, while cultivated land and grassland (UPA) had a negative impact on butterfly community. The distribution of butterfly species showed a significant difference between the two habitats. This suggests the effect of agricultural activities on the ecosystem. The species recorded in Ise Forest Reserve approximately $6.6 \%$ of all butterflies recorded in West Africa.

\section{Competing Interests}

The authors declare that they have no competing interests.

\section{References}

[1] R. B. Primak, Essentials of Conservation Biology, Sinauer Associates, Sunderland, Mass, USA, 1993.
[2] M. Konvicka, Z. Fric, and J. Benes, "Butterfly extinctions in European states: do socioeconomic conditions matter more than physical geography?" Global Ecology and Biogeography, vol. 15, no. 1, pp. 82-92, 2006.

[3] E. Pennisi, "Naturalists' surveys show that British butterflies are going, going," Science, vol. 303, no. 5665, p. 1747, 2004.

[4] D. Okali, "Many species. One planet. One future," in Proceedings of the Conference of the Institute of Ecology and Environmental Studies, vol. 3, pp. 1-11, Obafemi Awolowo University Ile-Ife, 2010.

[5] T. Kehinde, B. Amusan, A. Ayansola, S. Oyelade, and W. Adu, "Status of insect diversity conservation in Nigeria: a review," Ife Journal of Science, vol. 16, no. 2, pp. 319-330, 2014.

[6] M. Kitahara, K. Sei, and K. Fujii, "Patterns in the structure of grassland butterfly communities along a gradient of human disturbance: further analysis based on the generalist/specialist concept," Population Ecology, vol. 42, no. 2, pp. 135-144, 2000.

[7] J. Terborgh, Requiem for Nature, Island Press, Washington, DC, USA, 1999.

[8] C. Mora, D. P. Tittensor, S. Adl, A. G. B. Simpson, and B. Worm, "How many species are there on earth and in the ocean?" PLoS Biology, vol. 9, no. 8, Article ID e1001127, 2011.

[9] C. Van Swaay, T. Brereton, P. Kirkland, and M. Warren, "Manual for butterfly monitoring," Tech. Rep. VS2012.010, De Vlinderstichting/Dutch Butterfly Conservation, Butterfly Conservation UK \& Butterfly Conservation, Wageningen, the Netherlands, 2012.

[10] K. S. Brown Jr., "Diversity, disturbance, and sustainable use of Neotropical forests: insects as indicators for conservation monitoring," Journal of Insect Conservation, vol. 1, no. 1, pp. 2542, 1997.

[11] T. B. Larsen, Butterflies of West Africa 2 Volumes, 125 plates, Apollo Books, Stenstrup, Denmark, 2005.

[12] B. A. Akwashiki, G. A. Amuga, G. S. Mwansat, and R. J. Ombugadu, "Assessment of butterfly diversity in eagle owl gully of Amurum Forest Reserve, Jos East local government area, Plateau State, Nigeria," The Zoologist, vol. 5, pp. 33-38, 2007.

[13] C. Nwosu and C. Iwu, "A comparative study of the diversity of species of Butterflies in Protected and Unprotected habitats of Okuwu, Ogbaku forest reserve in Mbaitoli LGA, Imo State, Nigeria," Journal of Environmental Issues and Agriculture in Developing countries, vol. 3, no. 1, pp. 129-136, 2011.

[14] K. A. Kemabontal, A. S. Ebiyon, and F. Olaleru, "The Butterfly fauna of three varying habitats in South Western Nigeria," FUTA Journal of Research in Science, no. 1, pp. 1-6, 2015.

[15] A. Sundufu and R. Dumbuya, "Habitat preferences of butterflies in Bumbuna forest, Northern Sierra Leone," Journal of Insect Science, vol. 8, pp. 1-17, 2008.

[16] J. Majumder, R. Lodh, and B. K. Agarwala, "Variation in butterfly diversity and unique species richness along different habitats in Trishna wildlife sanctuary, Tripura, Northeast India," Check List, vol. 8, no. 3, pp. 432-436, 2012.

[17] M. L. Rosenzweig, "A theory of habitat selection," Ecology, vol. 62, no. 2, pp. 327-335, 1981.

[18] J. Majumder, R. Lodh, and B. K. Agarwala, "Butterfly species richness and diversity in the trishna wildlife sanctuary in South Asia," Journal of Insect Science, vol. 13, article 79, 2013.

[19] T. B. Larsen, "The Ghana butterfly fauna and its contribution to the objectives of the protected areas system," WDSP Report 63, Wildlife Division (Forestry Commission) and IUCN (World Conservation Union), 2006. 
[20] T. Larsen and M. Mei, "Butterflies from a Guinea transition area, the Parc National de Haut Niger (Republic of Guinea), with a description of a new subspecies of Platylesches robusta (Lepidoptera: Hesperiidae)," Bollettino della Società Entomologica Italiana, vol. 130, pp. 255-272, 1998.

[21] P. Viejo, L. Paul, and N. Curie, Conservation Biology, 1st edition, 2000. 

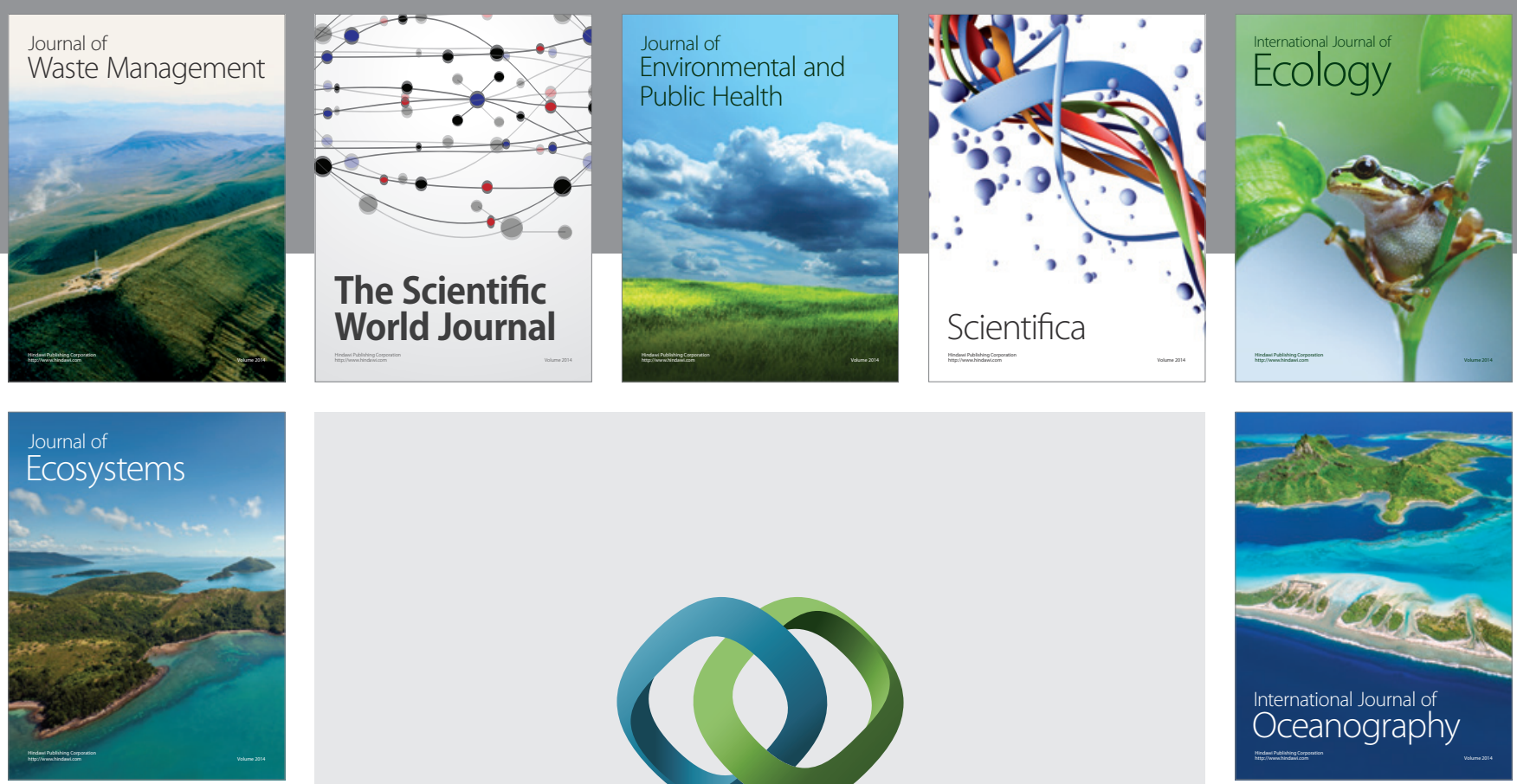

The Scientific World Journal
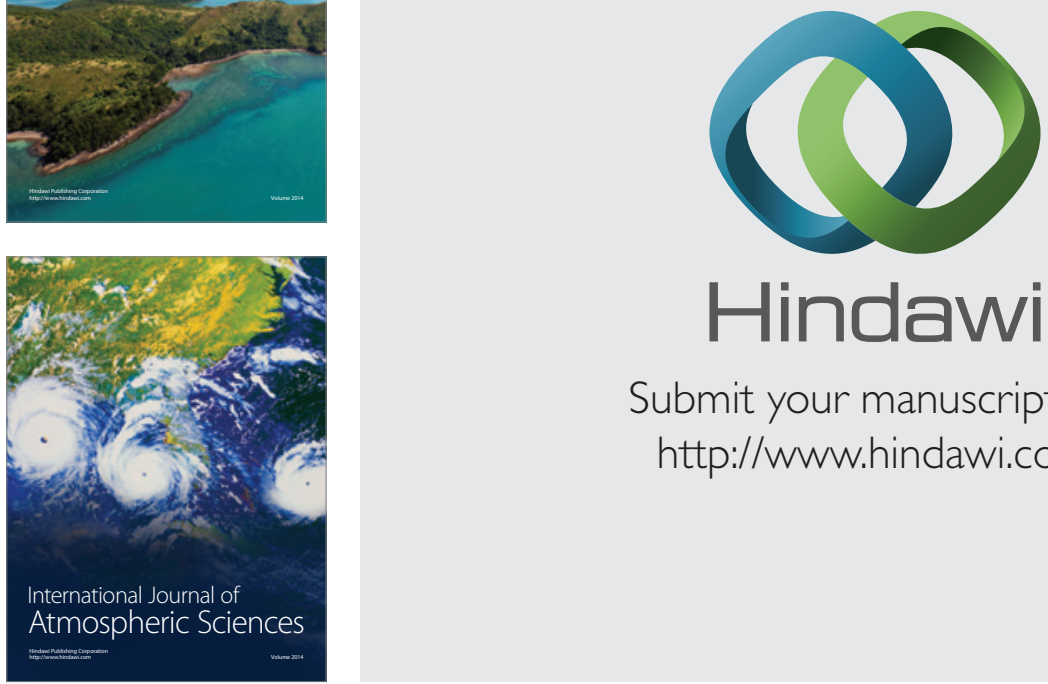

\section{Hindawi}

Submit your manuscripts at

http://www.hindawi.com
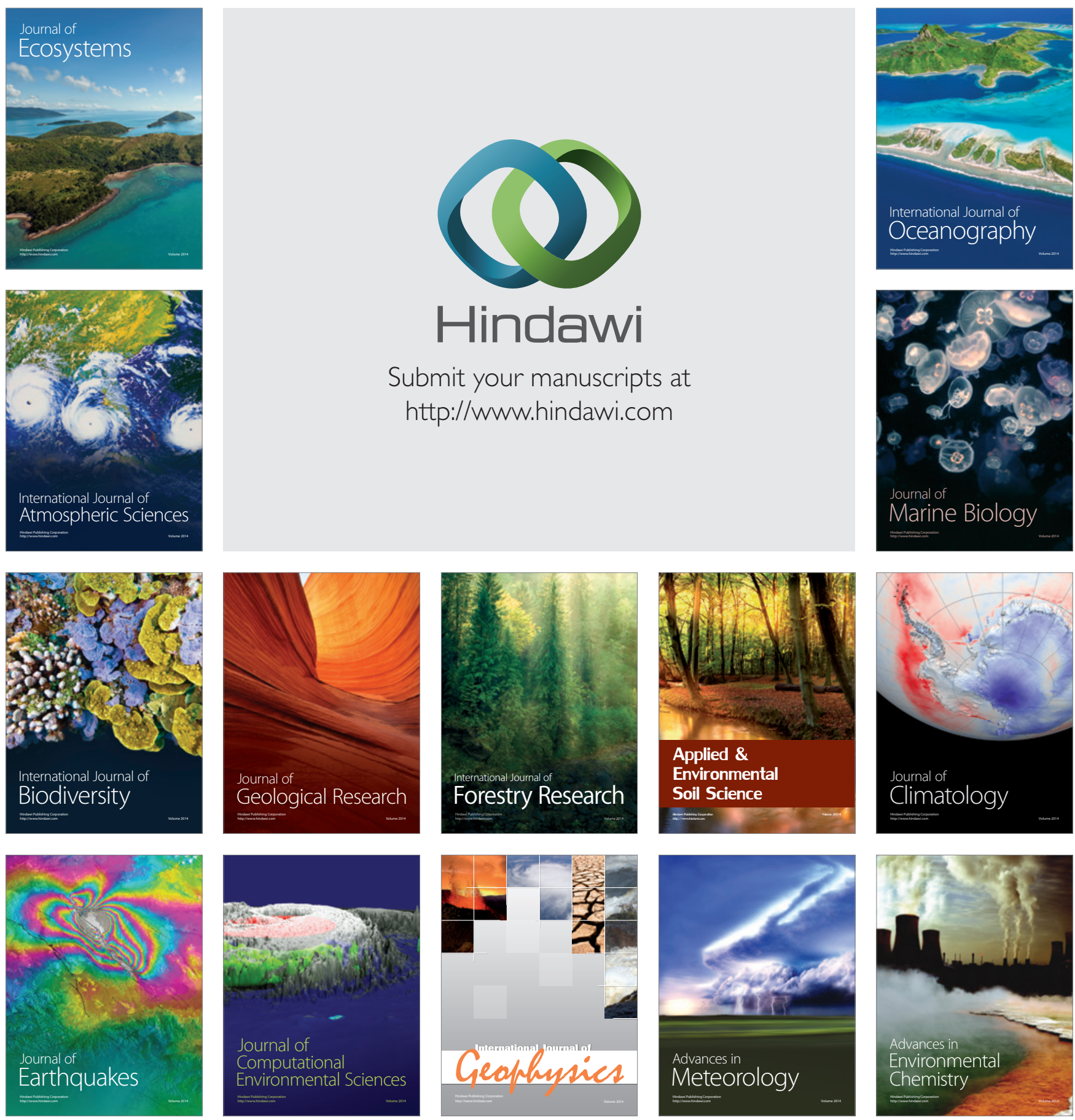